\title{
PEMBERDAYAAN PETANI AREN MELALUI DIVERSIVIKASI PRODUK OLAHAN AIR NIRA
}

\author{
Irwan Lalisang \\ Jurusan Pendidikan Ekonomi, Fakultas Ekonomi, Universitas Negeri Manado, Manado, Indonesia \\ *Penulis korespondensi: Irwan.lalisang@yahoo.com
}

\begin{abstract}
Abstrak
Gula Aren asal Lahendong dikenal sebagai gula aren yang benar-benar murni dari air nira. Gula Lahendong sangat disukai teristimewa untuk membuat kopi atau teh manis. Seiring dengan besarnya permintaan gula aren, baik di Kota Tomohon maupun di Kota Manado dan Airmadi di produksi gula aren asal Lahendong belum mampu memenuhi kebutuhan pasar. Masalah yang dihadapi para perajin belum melihat usaha gula aren menjadi usaha yang dapat diandalkan untuk meningkatkan pendapatan keluarga. Tujuan kegiatan IbM untuk memfasilitasi para perajin gula aren dan petani aren supaya dapat meningkatkan usaha mereka dan dapat menjadi usaha yang produktif. Metode yang digunakan adalah penyuluhan / edukasi, implementasi teknologi dan pendampingan dari tim IbM. Hasil yang dicapai dalam kegiatan ini mitra 1 dan mitra 2 diberikan penyuluhan tentang kewirausahaan. Tujuannya memotivasi para petani aren untuk tidak menjual air nira ke pabrik tetapi memproduksi sendiri menjadi gula aren dan gula semut. Memotivasi petani untuk memproduksi secara berkesinambungan. Hasil luaran yang dicapai adalah produksi gula semut yang telah dikemas dalam variasi ukuran.
\end{abstract}

Kata Kunci: Gula aren; air nira; usaha produktif, wirausaha

\begin{abstract}
Sugar Aren Lahendong origin known as palm sugar is really pure from the juice of water. Sugar Lahendong is especially preferred to make sweet coffee or tea. Along with the large demand for palm sugar, both in Tomohon City and in Manado City and Airmadi in the production of palm sugar from Lahendong has not been able to meet market needs. The problem faced by craftsmen has not seen palm sugar business become a reliable business to increase family income. The purpose of IbM's activities to facilitate the palm sugar craftsmen and palm farmers in order to improve their business and can be a productive business. The method used is counseling / education, technology implementation and mentoring of IbM team. The results achieved in this activity are partner 1 and partner 2 given counseling about entrepreneurship. The goal is to motivate the sugar palm farmers not to sell juice to the factory but to produce itself into palm sugar and sugar ants. Motivate farmers to produce on an ongoing basis. Output achieved is the production of ants sugar that has been packed in a variety of sizes.
\end{abstract}

Keywords: Palm sugar; water nira; productive enterprises, entrepreneurs

\section{PENDAHULUAN}

Gula Aren atau biasa disebut dengan gula merah. Di pasar global gula aren dikenal sebagai brown-sugar, tetapi ada juga yang menyebut palm sugar. Gula aren dihasilkan dari nira pohon enau dengan pengolahan yang masih terbilang tradisional. Nira dari pohon enau disadap dari pujuk/tangkai buah. Gula aren sudah dikenal sejak lama oleh masyarakat Indonesia, terutama penduduk pedesaan yang masih menggunakan gula aren sebagai gula konsumi seharihari disbanding dengan gula tebu. Gula aren mengandung beberapa unsur senyawa seperti: vitamin B kompleks, glukosa, garam mineral dan yang paling utama memiliki kadar kalori yang cukup tinggi diselingi dengan kadar glisemik gula terendah yakni 35 GI (Indeks Glisemik). Gula aren tidak hanya dapat dimanfaatkan sebagai gula padau mumnya yang dicampur dalam jenis makanan atau minuman atau panganan tertentu. (Filophy, 2016; Supangkat, 2014). Di samping penggunaannya, gula aren memiliki manfaat yang cukup banyak dalam bidang kesehatan, seperti : Meningkatkan sistem imunitas tubuh; Gula aren aman bagi penderita diabetes; dan lain-lain.

Lahendong merupakan salah satu desa yang ada di Kota Tomohon. Lahendong penghasil gula aren (sebutan bahasa lokal gula merah) yang dikenal bersih, tidak ada campuran bahan lainnya. Di daerah lain, biasanya gula aren diberi campuran buah pepaya 
pada saat proses pengolahan oleh para perajin gula aren. Gula merah asal Lahendong dikenal sebagai gula merah yang benar-benar murni dari air nira. Gula Lahendong sangat disukai teristimewa untuk membuat kopi atau teh manis. Seiring dengan besarnya permintaan gula merah, baik di Kota Tomohon maupun di Kota Manado dan Airmadidi produksi gula merah asal Lahendong tidak mampu memenuhi kebutuhan pasar. Apalagi, para pengrajin gula merah tidak rutin berproduksi. Mereka tidak berproduksi karena pasokan air nira tidak setiap hari. Bahkan sudah banyak pengrajin yang berhenti beroperasi, seiring dengan perubahan dan diversifikasi profesi warga desa. Ada yang beralih profesi menjadi tukang ojek, buruh tani harian, pekerja harian di proyek Pertamina Lahendong, dan lain-lain. Selain itu, para perajin gula aren terkendala kurangnya modal kerja, untuk membeli air nira sebagai bahan baku utama pembuatan gula aren. Para perajin tidak memanfaatkan peluang yang diberikan oleh pihak perbankan karena dari persyaratan pihak bank para perajin kurang memenuhi syarat, kaena tidak rutin beroperasi.

Proses pembuatan gula aren dilaksanakan secara tradisional dan dilakukan di kebun untuk memudahkan mendapatkan kayu bakar. Proses pembuatannya dapat dilihat pada gambar di bawah ini.

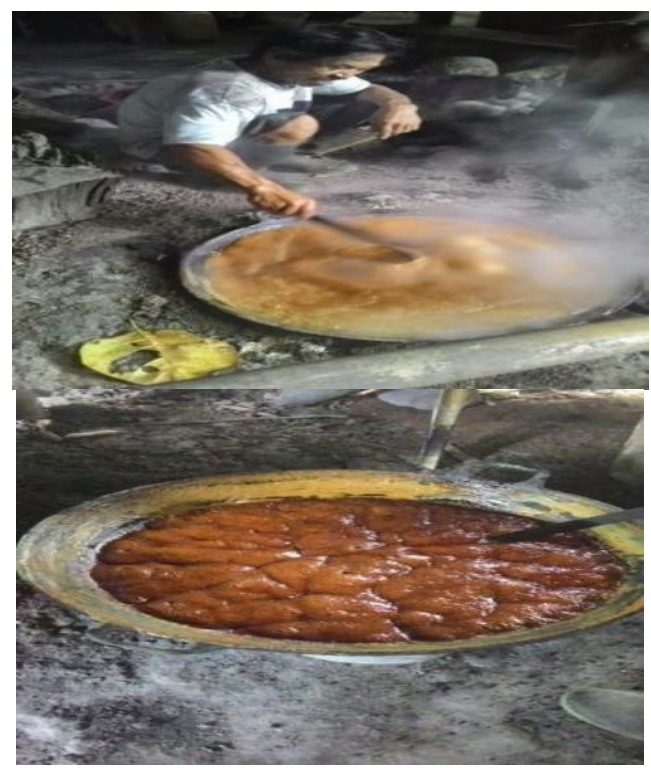

Gambar 1.1. Proses pembuatan gula aren

Kebutuhan gula merah semakin tinggi. Sebagai contoh, dapat disebut di sini yaitu salah satunya di Airmadidi. Ibukota Minahasa Utara ini terkenal sebagai wilayah penghasil kue-kue basah atau kue tradisional Minahasa yang banyak memakai bahan baku gula aren. Setiap harinya, pembuat kue basah membutuhkan puluhan bahkan ratusan gula merah untuk pembuatan kue. Permintaan yang cukup banyak dan rutin dari Airmadidi ini, ternyata tidak dapat dipenuhi para pengrajin gula merah dari Lahendong.

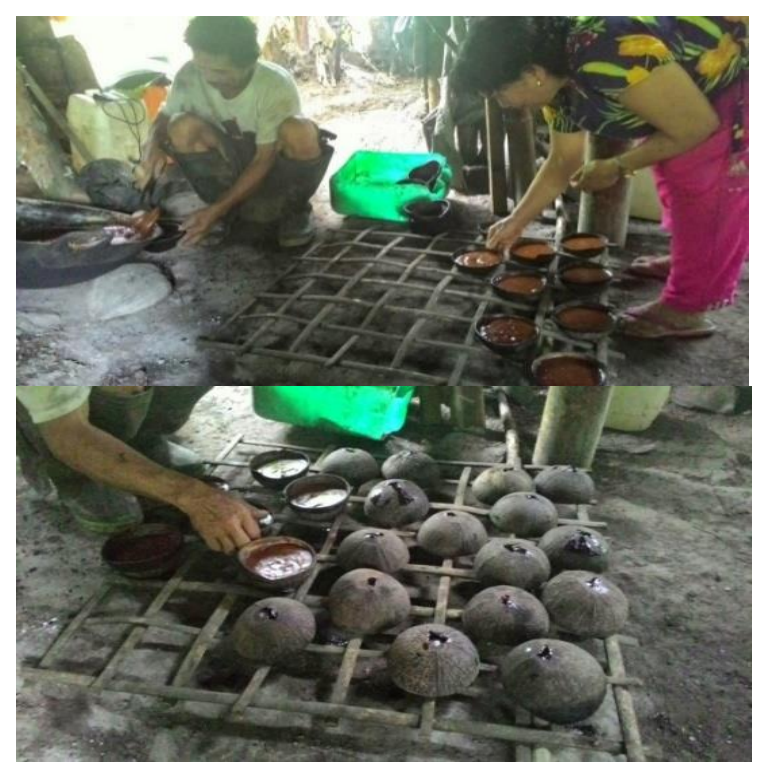

Gambar 1.2. Air nira yang sudah dimasak dimasukkan dalam wadah tempurung

Kendala lain, yaitu sejak 10 tahun terakhir, petani aren di Lahendong harus pula memenuhi permintaan bahan air nira oleh Yayasan Masarang melalui anak usahanya yang memproduksi gula semut untuk ekspor ke pasar Eropa, khususnya negeri Belanda. Padahal, jika petani aren hanya menjual bahan baku nira ke pabrik, sesungguhnya pendapatan mereka relatif kecil. Berbeda jika para petani/perajin aren mengolahnya sendiri memberi nilai tambah sehingga menjadi gula aren (merah). Bisa jadi pendapatan para petani akan semakin tinggi. Faktanya, para petani aren ini belum mampu berkreasi untuk mengembangkan profesi mereka dengan cara memberi nilai tambah, sehingga usaha yang digeluti semakin menguntungkan. Dengan menjual bahan mentah, mereka ingin secepatnya mendapat penghasilan walaupun harganya murah.

Hitung-hitungan sederhana seperti ini. Harga gula aren sebanyak 1 batu (istilah setempat untuk dua keping gula aren dalam 1 batu), yang ukurannya seperti pada gambar 1.3., dihargai oleh konsumen berkisar Rp 15.000 - Rp 17.5000. Harga ini dari tangan pertama (perajin) kepada konsumen akhir atau pedagang pengumpul yang datang membeli pada perajin. Sementara itu, harga jual di mini market atau di pasar tradisional menjadi $\mathrm{Rp} 20.000$,- untuk ukuran sedang, Rp 25.000,- untuk ukuran besar. Mereka tidak menggunakan alat takar kilogram, tetapi per buah. Gula yang mereka hasilkan ukurannya tidak sama ada yang besar ada yang sedang, sesuai dengan bentuk tempurung atau batok kelapa. 


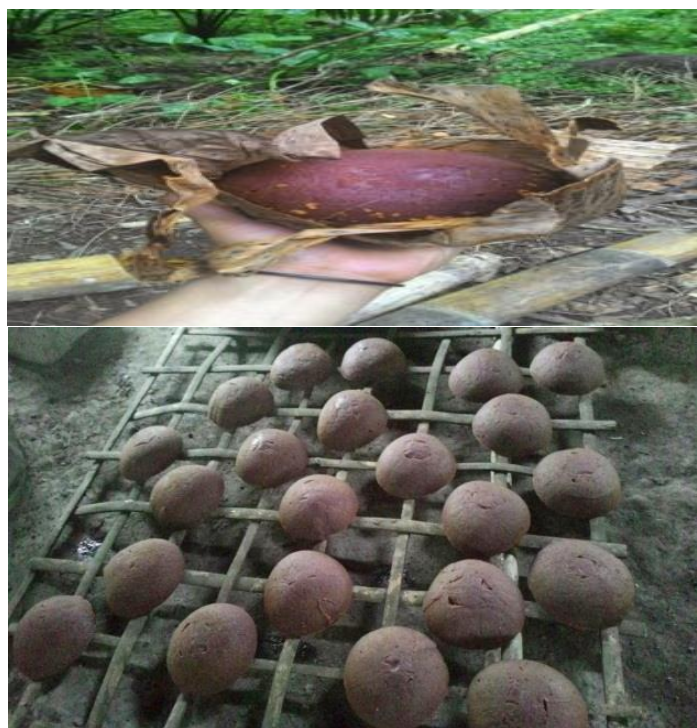

Gambar 1.3 Bentuk gula aren 1 batu terdiri dari 2 keping

Ketika tim melakukan kalkulasi dengan menambah biaya produksi, ternyata keuntungan yang diperoleh para perajin sangat kecil. Hanya sekitar Rp $2.000 \mathrm{~s} / \mathrm{d}$ Rp 3.000 per batu. Mengapa demikian, karena pengrajin hanya memproduksi dalam jumlah sedikit sehingga biaya produksi yang mereka korbankan, tidak sebanding dengan pendapatan, yang otomatis menurunkan nilai keuntungannya. Pengakuan para perajin gula aren, untuk setiap satu batu (atau sepasang) gula aren, mereka memerlukan bahan baku sebanyak lima liter air nira. Jika pengrajin membeli air nira per liter Rp 3.000,- maka harga pokok belum termasuk kayu bakar, dan lain-lain sudah mencapai Rp 15.000,- Berarti mereka bukan memperoleh laba tetapi kerugian. Dapat dimaklumi bahwa para perajin tidak terbiasa menghitung tenaga yang mereka pertaruhkan pada proses produksi. Bahan bakar kayu juga demikian. Karena hanya diambil di lahan sendiri, mereka pun belum menghitung hal ini sebagai faktor biaya produksi.

\section{BAHAN DAN METODE}

Berdasarkan permasalahan mitra atau subjek kegiatan maka untuk mencapai tujuan yang akan dicapai maka metode yang digunakan adalah sebagai berikut :

1. Sosialisasi

Metode ini digunakan untuk memberikan wawasan tentang kewirausahaan dan meningkatkan pemahaman pengetahuan dan ketrampilan dalam hal diversifikasi produk, sehingga dapat meningkatkan nilai tambah. Metode ini juga digunakan untuk meningkatkan pengetahuan mitra tentang manajemen usaha termasuk pembukuan.

2. Penyuluhan/Edukasi

Metode ini digunakan untuk meningkatkan pemahaman dan ketrampilan tentang upaya meningkat kan nilai tambah air nira menjadi gula semut dan gula aren cetak.

3. Pendampingan
Metode pendampingan digunakan untuk produksi gula semut dan pengemasan produk dan juga proses penerbitan ijin industry rumah tangga di Kantor Walikota Tomohon. Metode ini juga digunakan untuk memfasilitasi kelompok mitra dengan kepala Dinas UMKM Kota Tomohon.

Kelompok sasaran kegiatan ini adalah kelompok tani Hutan Lalayuan di Kelurahan Lehendong Kecamatan Tomohon Selatan Kota Tomohon. Jumlah anggota kelompok sebanyak 15 orang.

\section{HASIL DAN PEMBAHASAN}

\section{a) Peningkatan Pengetahuan Tentang Nilai Tambah Produk}

Hasil yang telah dicapai dalam kegiatan Pengabdian kepada Masyarakat ini berupa peningkatan pengetahuan tentang nilai tambah suatu produk. Anggota kelompok memahami tentang proses merubah bahan baku menjadi barang jadi. Dari segi ekonomi yang lebih menguntungkan Masyarakat jika dapat memprosses bahan baku alam menjadi barang jadi atau setengah jadi. Selain itu anggota kelompok memahami bagaimana memiliki jiwa wirausaha yaitu harus memiliki jiwa yang kreatif dan pantang menyerah. Luaran dari kegiatan ini yaitu produk gula semut yang telah dikemas dan didistribusikan kekonsumen yang ada disekitar kampus Universitas Negeri Manado.

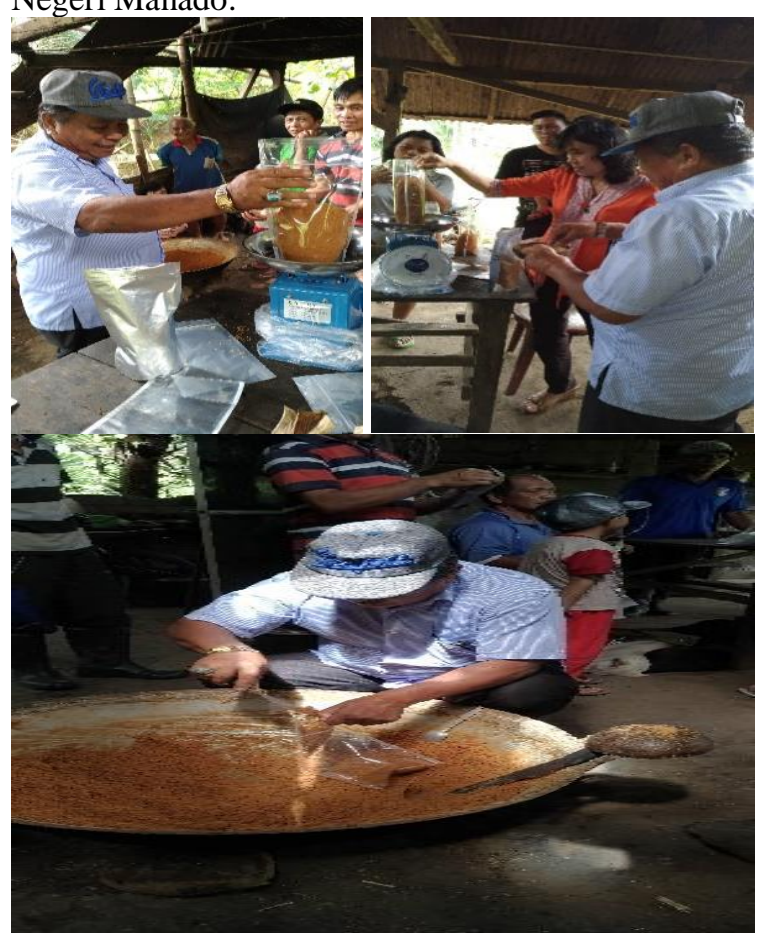

Gambar 1.4 Produk Gula Semut 

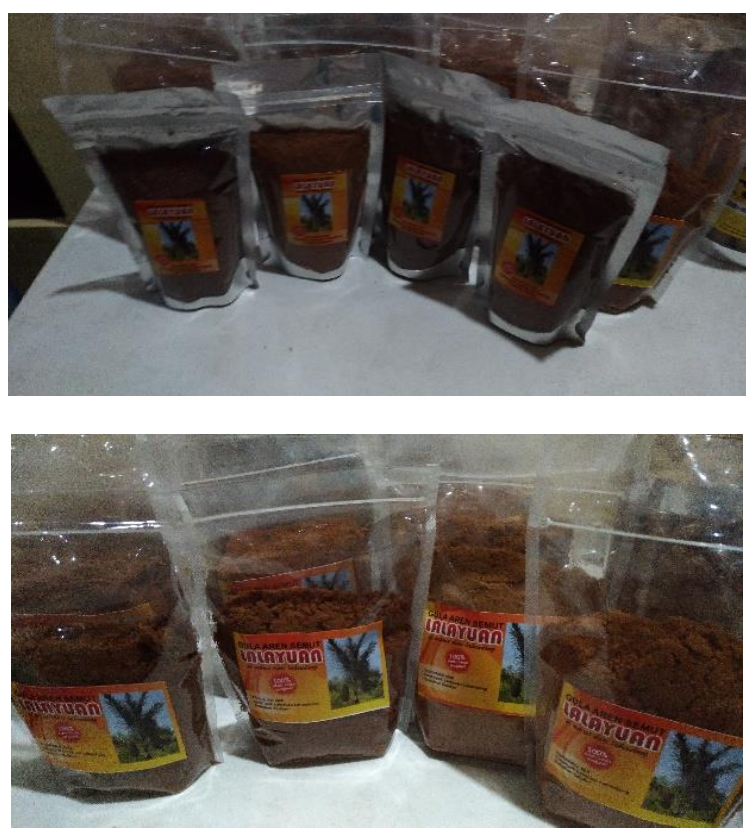

Gambar 1.5. Produk Gula Semut dalam Kemasan

\section{b) PeningkatanPendapatan}

Sebelum diadakan kegiatan Pengabdian kepada masyarakat, kelompok tani Lalayuan hanya menjual air nira kepada perusahaan Masarang yang memproduksi gula Kristal untuk dieksport ke Eropa. Setelah dikalkulasi pendapatan yang diterima oleh petaniarenjikahanyamenjual air niraharganya per liter Rp 1.000,- - Rp 2.000,- Padahal air nira yang dijual harus direbus terlebih dahulu sebelum dijual. Harganya bisa tinggi jika kadar gulanya tinggi. Jadi harganya ditentukan oleh perusahaan Masarang. Sedangkan setelah air nira diproses menjadi gula semut maka harga gula semut dalam kemasan sebagai berikut: kemasan 250 gram Rp 12.500,- ; kemasan ukuran 500 gram Rp 20.000,-; Kemasan ukuran 1000 gram Rp 35.000,-. Untuk menghasilkan $8,2 \mathrm{~kg}$ gula semut membutuhkan air nira sebanyak 60 liter. Jika dihitung 60 liter air nira harganya $\mathrm{Rp} 2.000$,- maka penghasilannya sebanyakRp 120.000 ,- Tetapi setelah menjadi gula semut yang menghasilkan 8,2 kg @ 35.000,- penghasilannya sebesar Rp 287.000,Selisihnya sebesar Rp 167.000,- Cukup signifikan. Keuntungan lebih besar jika produknya dikemas dalam ukuran kecil yang notabenenya dapat dijangkau oleh semua konsumen. Jika kemasan yang kecil harga $1 \mathrm{~kg}$ adalah Rp 50.000,-

\subsection{Pembahasan}

Pengamatan awal pola piker kelompok petani aren dan pengrajin gula aren masih memikirkan aspek kemudahan dalam mendapatkan hasil dari pekerjaan mereka meskipun tidak maksimal pendapatannya. Mereka tidak memproduksi air nira menjadi gula aren karena terhambat dalam pemasaran produk. Jika mereka memproduksi sudah dalam jumlah besar dan tidak ada pembeli maka mereka akan rugi karena tidak ada pendapatan untuk membiayai hidup setiap hari. Tidak mudah untuk merubah pola piker mereka karena perusahaan / pabrik memberikan kemudahan untuk penjualan air nira tersebut. Para petani tidak mengeluarkan sepeser pun untuk membawa air nira tersebut ke pabrik. Mereka hanya menunggu di kebun dan mobil perusahaan / pabrik datang menjemput air nira tersebut dan langsung membayar kepada petani.

Menjual air nira sangat tidak menguntungkan petani aren, karena sebelum dijual harus diproses dengan memasak terlebih dulu untuk mencegah air nira tersebut menjadi asam. Jika sudah asam maka tidak laku untuk dijual. Prosesnya sama dengan membuat gula aren yaitu dimasak, bedanya kalau gula aren masaknya sampai mengental tetapi kalau untuk dijual kepabrik hanya setengah matang saja. Perhitungan untung rugi, lebih menguntungkan jika para petani memproses air nira menjadi gula aren, tetapi harus dipersiapkan pemasarannya. Itulah kendala yang terpantau. Solusi yang akan diambil pada tahap selanjunya adalah mencari jaringan pemasaran yang tetap untuk produk gula aren.

Pola piker seperti di atas secara bertahap mulai berubah setelah diadakan kegiatan Pengabdian kepada masyarakat. Keberlanjutan perilaku wirausaha ini akan terjamin jika tetap ada pendampingan dari pihak yang terkait missal dinas UMKM, Dinas Perindustrian dan Perdagangan, dan juga unsur perguruan tinggi.

\section{KESIMPULAN}

Hasil kegiatan Pengabdian kepada Masyarakat dapat disimpulkan hal-hal sebagai berikut:

1. Terdapat perubahan pola piker dan perilaku para petani aren kearah mental wirausaha

2. Peningkatan pemahaman tentang upaya nilai tambah suatu produk

3. Terdapa peningkatan pendapatan dari anggota kelompok

\section{UCAPAN TERIMA KASIH}

Penghargaan dan ucapan terimakasih penulis sampaikan kepada pihak Direktorat Riset dan Pengembangan Dirjen Pendidikan Tinggi Kementerian Ristek dan Pendidikan Tinggi Republik Indonesia, yang telah memberikan dukungan dana sehingga kegiatan Pengabdian kepada Masyarakat dapat dilaksanakan.

\section{DAFTAR PUSTAKA}

Filophy Andre, www.dunia-info-kesehatan, diakses tanggal 24 April 2016

http://tanamanobatherbal.blogspot.com/2013/07/kand ungan-dan-manfaat-gula-aren.html, diakses tanggal 23 April 2016

http://www.organisasi.org/1970/01/isi-kandungangizi-gula-aren-komposisi-nutrisi-bahanmakanan.html, diakses tanggal 23 April 2016 